Gut, 1969, 10, 575-576

\title{
Degradation of bile salts by human intestinal bacteria
}

\author{
VIVIENNE ARIES, J. S. CROWTHER, B. S. DRASAR, AND M. J. HILL \\ From the Bacteriology Department, Wright-Fleming Institute, St Mary's Hospital Medical \\ School, London
}

We have previously reported that many strains of enterococci and the strictly anaerobic bacteria of the intestine (Bacteroides, Bifidobacteria, Clostridia, and Veillonella) hydrolyse bile acid conjugates (Drasar, Hill, and Shiner, 1966; Hill and Drasar, 1968). More detailed studies on the deconjugating enzyme, cholanylglycine hydrolase, obtained from Bacteroides spp, Bifidobacterium spp, Clostridium spp, and Strep. faecalis (two strains of each) are reported elsewhere (Aries and Hill, 1969). Here we report our studies on the metabolism of cholate and deoxycholate, and further studies on deconjugation.

\section{METHODS}

Samples of faeces from normal persons living on a mixed diet in England, and from normal persons living on a vegetarian diet in Uganda were examined bacteriologically using the methods described previously (Drasar, 1967), modified to facilitate the isolation and identification of Bacillus spp, Pseudomonas spp and anaerobic Sarcina. The differences between the faecal flora of Ugandans and English people are discussed elsewhere (Aries, Crowther, Drasar, Hill and Williams, 1969).

The bacteria were grown at $37^{\circ} \mathrm{C}$ under the conditions listed in Table I. Bacteria from $50 \mathrm{ml}$ of broth culture were harvested by centrifugation and resuspended in $0.5 \mathrm{ml}$ of supernatant. This suspension was mixed with $0.5 \mathrm{ml}$ of a $0.1 \%$ solution of substrate (taurocholate, cholic acid, or deoxycholic acid) in $0.02 \mathrm{M}$ phosphate buffer solution $p \mathrm{H} 7$ and incubated at $37^{\circ} \mathrm{C}$ for 48 hours. Degradation products were separated by thin layer chromatography on silica gel G (Merck) using the solvents described by Eneroth (1963). Standard solutions were included on all plates; these contained sodium taurocholate (Maybridge Research Chemicals Ltd, Launceston, Cornwall), cholic acid, deoxycholic acid, chenodeoxycholic acid, lithocholic acid (all from KochLight Laboratories), cholanic acid (Steraloid Ltd), 7 ketodeoxycholic acid, 12 keto lithocholic acid, and 7,12 diketo lithocholic acid, all prepared by oxidation methods from the parent hydroxyl compound (Fieser and Rajagopolan, 1949; Bergstrom and Haslewood, 1939).
TABLE I

GROWTH MEDIA AND CONDITIONS OF THE VARIOUS ORGANISMS STUDIED

\begin{tabular}{|c|c|c|c|c|}
\hline Bacteria & Medium & $\begin{array}{l}\text { Period of } \\
\text { Growth } \\
\text { (hr) }\end{array}$ & Atmosphere & $\begin{array}{l}\text { Other } \\
\text { Conditions }\end{array}$ \\
\hline $\begin{array}{l}\text { Enterobacteria } \\
\text { Enterococci }\end{array}$ & $\begin{array}{l}\text { Glucose broth } \\
\text { Glucose broth }\end{array}$ & $\begin{array}{l}24 \\
24\end{array}$ & $\begin{array}{l}\text { Air } \\
\text { Air }\end{array}$ & \\
\hline $\begin{array}{l}\text { Enterococci } \\
\text { Str. salivarius }\end{array}$ & $\begin{array}{l}\text { Glucose broth } \\
\text { Reinforced } \\
\text { clostridial } \\
\text { medium }\end{array}$ & $\begin{array}{l}24 \\
48\end{array}$ & $\begin{array}{l}\text { Air } \\
\text { Air }\end{array}$ & \\
\hline Lactobacilli & $\begin{array}{l}\text { Reinforced } \\
\text { clost ridial } \\
\text { medium }\end{array}$ & 48 & $\begin{array}{l}90 \% \mathrm{CO}_{2}+ \\
10 \% \text { air }\end{array}$ & \\
\hline Clostridia & $\begin{array}{l}\text { Reinforced } \\
\text { clostridial } \\
\text { medium }\end{array}$ & 48 & $\begin{array}{l}10 \% \mathrm{CO}_{2} \\
\text { in } \mathrm{H}_{2}\end{array}$ & \\
\hline Veillonella & $\begin{array}{l}\text { Reinforced } \\
\text { clostridial } \\
\text { medium }\end{array}$ & 72 & $\begin{array}{l}10 \% \mathrm{CO}_{2} \\
\text { in } \mathrm{H}_{2}\end{array}$ & \\
\hline Bacteroides & $\begin{array}{l}\text { Reinforced } \\
\text { clostridial } \\
\text { medium }\end{array}$ & 72 & $\begin{array}{l}10 \% \mathrm{CO}_{2} \\
\text { in } \mathrm{H}_{2}\end{array}$ & \\
\hline Bifidobacteria & $\begin{array}{l}\text { Reinforced } \\
\text { clostridial } \\
\text { medium }\end{array}$ & 72 & $\begin{array}{l}10 \% \mathrm{CO}_{2} \\
\text { in } \mathrm{H}_{2}\end{array}$ & \\
\hline $\begin{array}{l}\text { Bacillus spp } \\
\text { Anaerobic } \\
\text { Sarcina }\end{array}$ & $\begin{array}{l}\text { Glucose broth } \\
\text { Reinforced } \\
\text { clostridial } \\
\text { medium }\end{array}$ & $\begin{array}{l}24 \\
24\end{array}$ & $\begin{array}{l}\text { Air } \\
10 \% \mathrm{CO}_{2} \\
\text { in } \mathrm{H}_{2}\end{array}$ & Shaking \\
\hline
\end{tabular}

\section{RESULTS}

Groups of organisms unable to deconjugate sodium taurocholate in the more concentrated solutions used in our previous studies were unable to do so in the dilute solutions used here.

Many strains of Bacteroides spp, Bifidobacterium spp, Clostridium spp, Veillonella spp and enterococci were able to degrade cholate and deoxycholate yielding one or more products (Table II). Strains of these genera also deconjugated bile salts. In addition, many enterobacteria, none of which were able to deconjugate bile salts, were able to metabolize the bile acids. The reaction was subject to substrate inhibition and very little reaction with $0.5 \%$ cholate was detected (Hill and Drasar, 1968). 
TABLE II

ORGANISMS ABLE TO DEGRADE TAUROCHOLATE, CHOLATE, AND DEOXYCHOLATE

\begin{tabular}{|c|c|c|c|c|c|}
\hline \multirow[t]{2}{*}{ Organism } & \multirow{2}{*}{$\begin{array}{l}\text { Source } \\
\text { of } \\
\text { Faeces }\end{array}$} & \multirow{2}{*}{$\begin{array}{l}\text { No. } \\
\text { Tested }\end{array}$} & \multicolumn{3}{|c|}{ Percentage Able to Degrade Bile } \\
\hline & & & Taurocholate & Cholate & Deoxycholate \\
\hline \multirow[t]{2}{*}{ Enterobacteria } & Uganda & 180 & 0 & 53 & 32 \\
\hline & England & 87 & 0 & 78 & 39 \\
\hline \multirow[t]{2}{*}{ Enterococci } & Uganda & 162 & 90 & 68 & 18 \\
\hline & England & 90 & 93 & 81 & 29 \\
\hline \multirow[t]{2}{*}{ Str. salivarius } & Uganda & 37 & $\mathbf{0}$ & 0 & $\mathbf{0}$ \\
\hline & England & 45 & 0 & 0 & $\mathbf{0}$ \\
\hline \multirow[t]{2}{*}{ Lactobacilli } & Uganda & & & & \\
\hline & $\begin{array}{l}\text { and } \\
\text { England }\end{array}$ & 48 & $\mathbf{0}$ & 0 & $\mathbf{0}$ \\
\hline \multirow[t]{2}{*}{ Clostridia } & Uganda & 60 & 96 & 91 & 43 \\
\hline & England & 70 & 94 & 87 & 47 \\
\hline \multirow[t]{2}{*}{ Bifidobacteria } & Uganda & 137 & 86 & 47 & 18 \\
\hline & England & 57 & 74 & 56 & 21 \\
\hline \multirow[t]{2}{*}{ Bacteroides } & Uganda & 17 & 71 & 48 & 18 \\
\hline & England & 37 & 82 & 79 & 30 \\
\hline \multirow[t]{2}{*}{ Bacilli } & Uganda & 36 & 11 & 25 & $\mathbf{0}$ \\
\hline & England & 45 & 49 & 9 & 0 \\
\hline \multirow[t]{2}{*}{ Veillonella } & Uganda & 72 & 36 & 19 & 1 \\
\hline & England & 20 & 95 & 90 & 30 \\
\hline Anaerobic & Uganda & 12 & 67 & 58 & $\mathbf{0}$ \\
\hline
\end{tabular}

(It is possible that a higher proportion of strains would prove to be active at still lower substrate concentrations.)

A number of strains of each of the active genera are under more extensive investigation. In general the enterobacteria produce only a single degradation product from cholic acid, usually 7 ketodeoxycholate. The Bacteroides and Clostridia are much more active, producing a number of products, some of which have been identified as deoxycholic acid, lithocholic acid, and possibly cholanic acid together with 7 ketodeoxycholate. In addition, a number of products in which the $\alpha$ hydroxyl groups have been inverted to the $\beta$ form (presumably by way of keto intermediates) have been tentatively identified.

\section{DISCUSSION}

The conversion of cholate to deoxycholate (Midtvedt, 1967; Coccucci, and Ferrari, 1963) and other products by bacteria is now well documented. Midtvedt and Norman (1967) have screened a number of anaerobic bacteria and identified the products of cholate metabolism as $3 \alpha 12 \alpha$ dihydroxy 7 keto cholanate, $3 \alpha$ hydroxy 7,12 diketo cholanate, and $3,7,12$ triketo cholanate. We have not detected the two latter metabolites but this may be a result of the reaction conditions; Midtvedt used a much lower substrate concentration and incorporated it in the growth medium. The concentration used in our work $(0.05 \%)$ is the lowest that can conveniently be used with our detection methods.

In conclusion, our results demonstrate that, in the metabolism of bile salts and acids by intestinal bacteria, the strictly anaerobic bacteria are of major importance. Our investigations on human faecal steroids indicate that this is probably true in vivo as well as in the situation in vitro described here.

We would like to acknowledge the financial support of the Medical Research Council (M.J.H. and B.S.D.) and the British Empire Cancer Campaign (V.C.A. and J.S.C.). We would also like to thank Miss Rosalind Steward and Miss Rosalind Scutt for their technical assistance and Professor R. Blowers for obtaining the Ugandan faecal samples for us.

\section{REFERENCES}

Aries, V. C., Crowther, J. S., Drasar, B. S., Hill, M. J., and Williams R. E. O. (1969). Bacteria and the aetiology of large-bowel cancer. Gut, 10, 334-335

Bergstrom, S., and Haslewood, G. A. D. (1939). Substituted ketocholanic acids. J. chem. Soc., 540-541.

Coccucci, M. D., and Ferrari, A. M. (1963). Transformazione dell'acido colico in desossicolico ad opera di un batterio sporigeno anaerobico, in coltura pura, proveniente da feci umane. R.C. Ist. lomb. Sci. Lett., B, 97, 398-404.

Drasar, B. S. (1967). Cultivation of anaerobic intestinal bacteria. J. Path. Bact., 94, 417-427.

- Hill, M. J., and Shiner, M. (1966). The deconjugation of bile salts by human intestinal bacteria. Lancet, 1, 1237-1238.

Eneroth, P. (1963). Thin-layer chromatography of bile acids. J. Lipid Res., 4, 11-16.

Fieser, L. F., and Rajagopolan, S. (1949). Selective oxidation with N-bromosuccinimide. 1. Cholic acid. J. Amer. chem. Soc., 71, 3935-3938.

Hill, M. J., and Drasar, B. S. (1968). Degradation of bile salts by human intestinal bacteria. Gut, 9, 22-27.

Midtvedt, T. (1967). Properties of anaerobic Gram-positive rods capable of 7a-dehydroxylating bile acids. Acta path. microbiol. scand., 71, 147-160.

- , and Norman, A. (1967). Bile acid transformations by microbial strains belonging to genera found in intestinal contents. Ibid., 71, 629-638. 